\title{
Activity of Trigonella foenum-graecum on Some Cell Lines
}

\author{
Kurnia Agustini*, Wahono Sumaryono, and R. Micho Widyanto \\ Center for Pharmaceuticals and Medical Technology \\ Laboratory for Development of Industrial Agro and Biomedical Technology \\ Agency for the Assessment and Application of Technology (BPPT) \\ Kawasan PUSPIPTEK, Serpong - Indonesia
}

\begin{abstract}
Trigonella foenum-graecum (TFG) is one of medicinal plants contains some steroidal sapogenin such as diosgenin, yamogenin, gitogenin, tigogenin and trigoneoside, also alkaloid trigonellin, which is have many activity as antidiabetic, estrogenic and also as anti cancer. This experiment was done to explore the activity of some extract of TFG on some cell lines such as MCF7 (Human Breast Cancer Cell-line), T47D (Human Breast Cancer Cell-line), PC3 (Human Prostate Cell-line) and SKOV (Human Ovarian Carcinoma Cell-line). This assay was done using MTT (3-(4,5-Dimethylthiazol-2-yl)-2,5-Diphenyltetrazolium) methods. Results showed that ethyl acetate fraction gives the lowest IC50 than another extracts. IC50 for PC3 is 66.24 ppm, IC50 for MCF7 is 4I.8I Ppm, IC50 for T47D is $58.63 \mathrm{ppm}$. These datas can be used for further research to isolate the active compound from TFG.
\end{abstract}

Keywords: Trigonella foenum-graecum, MCF-7, T47D, SKOV, PC3.

\section{INTRODUCTION}

Fenugreek seed or Foenigraeci semen is dried seed from Trigonella foenum-graecum L., Leguminosae, (Anonim, 1979).Geographical distribution of Fenugreek is indigenous to the Mediterranean region, China, India and Indonesia. Fenugreek contains alkaloids (trigonelline, an alkaloid pyridine, gentianin and karpain), flavonoids e.g. vitexin in glycoside or ester form,isovitexin, orientin, vicenin, quercetin and luteolin, some sapogenin steroid ingredients, e.g. diosgenin, precursor for sexual hormone (Evans, 2002), its isomer Yamogenin (Dewick, 1997), gitogenin, tigogenin, and trigoneoside (saponine like estrogen) which have effect as phytoestrogen for menopause symptoms therapy.Fenugreek contains diosgenin in base free form $0.8-2.2 \%$. Fenugreek also contains fatty oil $20-30 \%$, essential oil, saponine, nicotinamide, choline, bitter compound and mucilage (Evans, 2002).
Empirically fenugreek was use as aphrodisiac, carminative, diuretic, emmenagogue, emollient, galactogogue and tonic. Many researches, preclinically and clinically, showed that fenugreek have activity for diabetic disease (Annida and Stanley 2004).Fenugreek also have estrogenic effect, as Phytoestrogen, predicted by its sapogenin steroid contains (Agustini, 2007). It can induce uterine contraction, so it should be avoided during pregnancy. Phytoestrogen is used as alternative for Hormone Replacement Therapy (HRT) to help reducing menopause symptoms. It can be used for long term until the body can make adaptation on the new level hormone (Badziad, 2003).

\footnotetext{
*Corresponding author email : kurnia_atini@yahoo.com
} 


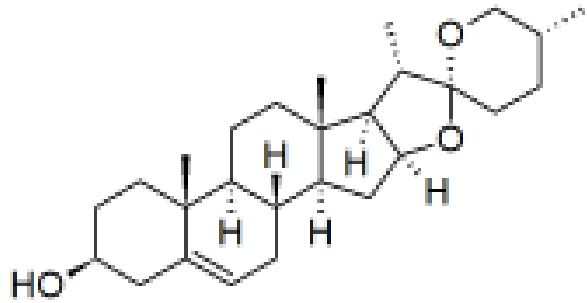

A

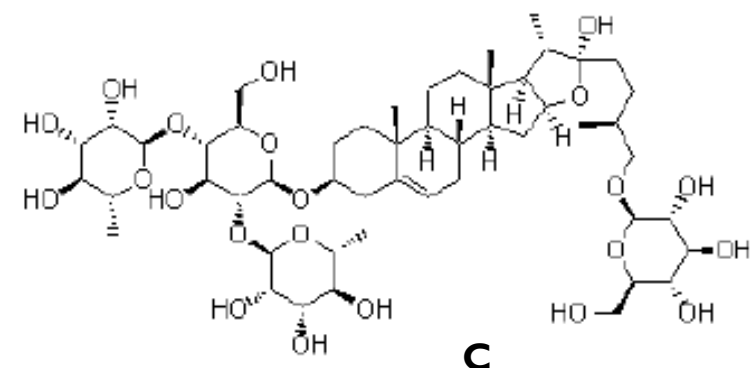

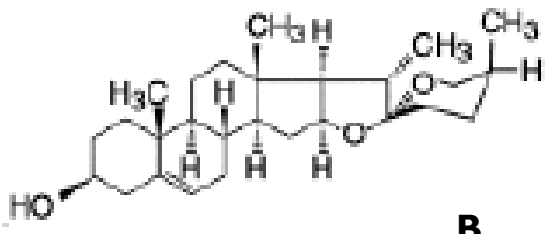

B

Figure I. Some chemicals contains of Trigonella foenum-graecum L. Diosgenin (A), Yamogenin (B), Protodioscin (C), and Tigogenin (D).

Medicinal plants have been widely used for cancer treatment both as prevention and treatment. In contrast to cancer treatment using synthetic drug that can be given as a primary drug or as an additional therapy (adjuvant), treatment with medicines derived from plants can also be intended for prevention (chemopreventive). The aim of treatment is approximately similar by synthetic drugs such as chemotherapy; immunotherapy or palliative therapies and cancer pain, in practice, always use the combination therapy treatment of several kinds of medicinal plants by also predicting the side effects that may occur (Ma'at, 2003).

Cancer is a malignant neoplasm and a growing network of small pieces that become large and unmanageable. To date approximately 120 types of cancer are known and classified in 12 major parts, namely: uterine cancer, breast, respiratory system, digestive organs, bones and muscles, urinary tract, skin, lymph, blood, eyes, gastrointestinal tract and nervous system (Saputra et al., 2000). Cancer treatment is medically requiring a very high cost. Clinically, the common cancer treatments are surgery, radiation and chemotherapy. In addition to these conventional treatments, also develop treatment using natural ingredients.

Screening for anticancer from medicinal plants has already done for many years ago in many research institute in the world, and sometimes it takes a long time research. Meanwhile, many medicinal plants which empirically has been used but have no scientific data. Cytotoxicity test using human or animal cell- lines are often used as a preliminary test in order to search for new cancer drugs. Antiviral and anticancer drug is a compound inhibiting cell growth without damaging the normal cells. According to the definition of National Cancer Institute (NCI) cytotoxicity test is only a test of toxicity to cells (tumors) in the media. Screen of the next antitumor or antineoplastic should be done by in vivo experiment. The term of anti cancer can be used when the results of clinical trials in human already done (Scheuer, 1987).

Refer to data that showed TFG having estrogenic activity as phytoestrogen, inspiring to study its possibility as Selective Estrogen Receptor Modulators (SERMs) candidate. SERMs such as tamoxifen, which are used clinically for the treatment of breast cancer, act as estrogen agonists in certain tissues but exhibit antiestrogenic effects in others (Rosenbaum and Osborne, 2000). There are several researches about SERMs candidates for post tumor surgery therapy from phytoestrogen pure compounds, such as dammarane, a sapogenine steroid from ginseng (Oh et al., 1999), Genistein (an isoflavone from soybean) and resveratrol, a stilbene from grape (Baht et al., 2001).

\section{MATERIALS AND METHODS}

\section{Samples Preparation}

TFG seeds were obtained from Tawangmangu, Central Java, Indonesia. Seeds were dried and grind, then were extracted with methanol and ethanol. The methanolic extract was 
fractioned with nhexane, ethylacetic (EtOAc) and n-buthanol. Every extract and fraction was dried with vacuum rotary evaporator.

\section{Cell Culture}

The cell lines PC3 (Human Prostate Cancer), SKOV3 (Human Ovarian Carcinoma), MCF-7 (Human Breast Adenocarcinoma), T47D (Human Breast Cancer) were obtained from Laboratory for Development of Industrial Agro and Biomedical Technology (LAPTIAB-BPPT) Indonesia. Cells were routinely maintained and grown in $75 \mathrm{~cm} 2$ flasks at $370 \mathrm{C}, 5 \% \mathrm{CO} 2$ and in a 95\% humidified atmosphere. The growth medium was prepared as following : RPMI 1640,Gibco life Technologies with phenol red and $2 \mathrm{mM}$ glutamine, $100 \mathrm{U} / \mathrm{ml}$ penicillin, $0.1 \mathrm{mg} / \mathrm{ml}$ Streptomycin, $1 \mathrm{mM}$ sodium pyruvate and supplemented with 10\% Foetal Bovine Serum (FBS, Gibco Life Technologies) which already heat inactivated at $560 \mathrm{C}$ for $30 \mathrm{~min}$. Passaging of cells was carried out using $4 \mathrm{ml}$ of trypsin-EDTA at room temperature for $75 \mathrm{~cm} 2$ flask, respectively for $3 \mathrm{~min}$. After that, $10 \mathrm{ml}$ media with 10\% FBS were used to reduce the action of trypsin on cells. After centrifugation, the obtained cells were platted.

\section{Cytotoxicity Test with MTT Method}

Cells were platted into 96-well plates (10,000 cells/well) in medium RPMI with phenol red containing 10\% Fetal Bovine Serum (FBS), $100 \mathrm{U} / \mathrm{ml}$ penicillin, $0.1 \mathrm{mg} / \mathrm{ml}$ streptomycin and
$1 \mathrm{mM}$ sodium pyruvate, then incubated for 24 hours at $370 \mathrm{C}, 5 \% \mathrm{CO} 2$ and in a 95\% humidified atmosphere. After 24 hours, medium was changed with samples (extracts and phases of TFG) in growth medium in different concentration and incubated for another 24 hours at $370 \mathrm{C}, 5 \% \mathrm{CO} 2$ and in a $95 \%$ humidified atmosphere. Assays were done in wide range concentration, from $10 \mathrm{ppm}$ until $500 \mathrm{ppm}$, divide into six variation concentration.

After 24 hours treatment, the cells were washed with Phosphate Buffer Saline (PBS).Then the MTT (3-(4,5- Dimethylthiazol-2-yl)-2,5 Diphenyltetrazolium) solution in medium, was added followed by incubation for 4 hours

at $370 \mathrm{C}, 5 \% \mathrm{CO} 2$ and in a 95\% humidified atmosphere. The crystal of formazan blue will be formed. After that, reaction was stopped by added Sodium Dodecyl Sulphate (SDS) into every well. Leave plate in dark place for 12 hours (overnight). The intensity of the color formed was measured by ELISA reader at $570 \mathrm{~nm}$.

\section{RESULTS AND DISCUSSION}

Results of percentage growth of SKOV cells, MCF7 cells, T47D cells and PC3 cells were performed in table I - table IV and Fig. 2-5. Each data was presented from 6 (six) concentration variation, with $\mathrm{n}=3$.

Table I. Percentage growth of Trigonella foenum-graecum on SKOV3 cells $(n=3)$

\begin{tabular}{cccc}
\hline \multirow{2}{*}{$\begin{array}{c}\text { Concentration } \\
(\mathbf{p p m})\end{array}$} & EtOH extr. & MetOH extr. & EtOAc Phase \\
\cline { 2 - 4 } & 106.36 & 96.87 & 102.80 \\
10 & 106.64 & 96.17 & 96.28 \\
20 & 89.97 & 77.08 & 96.33 \\
50 & 97.09 & 53.31 & 96.87 \\
10 & 42.50 & 20.44 & 28.53 \\
250 & 12.24 & 12.24 & 12.89 \\
500 & & & \\
\hline
\end{tabular}




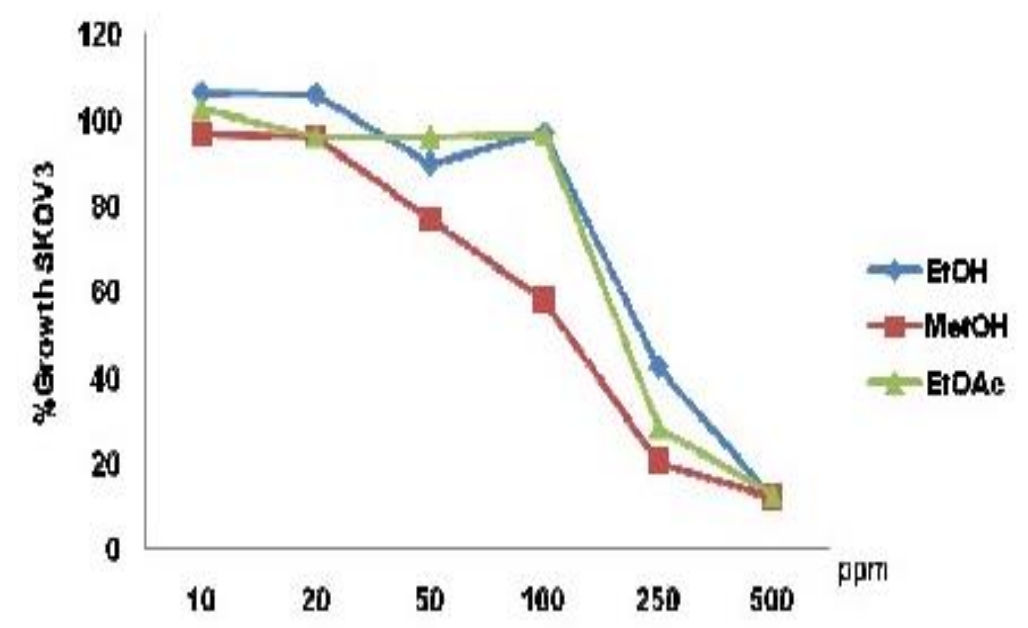

Figure 2. Effect of TFG on growth of SKOV3 cells. The results were plotted as percent of SKOV3 growth (relative cell growth $(\%)$ ) versus concentration part permillion $(\mathrm{ppm})(\mathrm{n}=3)$

Table II. Percentage growth of Trigonella foenum-graecum on MCF7 cells ( $n=3)$

\begin{tabular}{ccccccc}
\hline \multirow{2}{*}{$\begin{array}{c}\text { Concentration } \\
(\mathbf{p p m})\end{array}$} & $\begin{array}{c}\text { MetOH } \\
\text { extr. }\end{array}$ & $\begin{array}{c}\text { EtOH } \\
\text { extr. }\end{array}$ & $\begin{array}{c}\text { EtOAc } \\
\text { Phase }\end{array}$ & $\begin{array}{c}\text { Hexan } \\
\text { Phase }\end{array}$ & $\begin{array}{c}\text { BuOH } \\
\text { Phase }\end{array}$ & $\begin{array}{c}\text { Water } \\
\text { Phase }\end{array}$ \\
\cline { 2 - 7 }$y$ \\
10 & 110.61 & 116.21 & 78.72 & 75.17 & 107.74 & 100.89 \\
20 & 111.21 & 111.33 & 78.54 & 92.71 & 97.80 & 107.95 \\
50 & 98.67 & 119.53 & 30.20 & 82.82 & 73.13 & 102.25 \\
10 & 46.65 & 67.57 & 19.47 & 46.90 & 32.25 & 100.05 \\
250 & 18.57 & 18.63 & 17.96 & 18.99 & 20.54 & 92.21 \\
500 & 17.06 & 17.60 & 17.90 & 18.87 & 18.82 & 73.34 \\
\hline
\end{tabular}

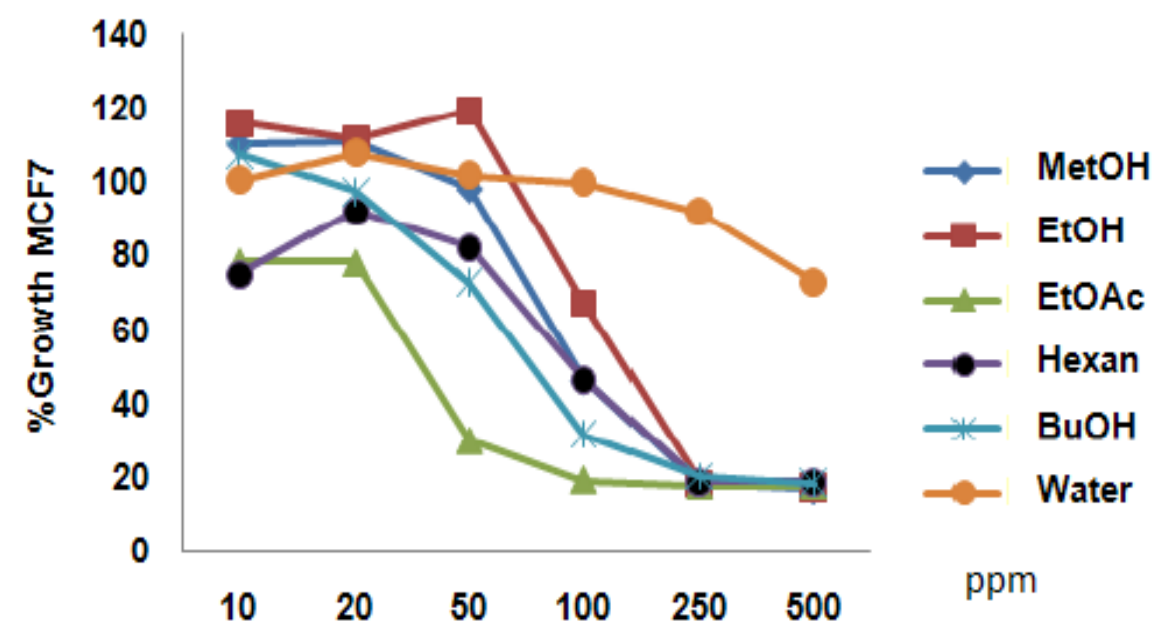

Figure 3. Effect of TFG on growth of MCF7 cells. The results were plotted as percent of MCF7 growth (relative cell growth $(\%)$ ) versus concentration part permillion $(\mathrm{ppm})(\mathrm{n}=3)$ 
Table III. Percentage growth of Trigonella foenum graecum on T47D cells $(n=3)$

\begin{tabular}{ccccc}
\hline \multirow{2}{*}{$\begin{array}{c}\text { Concentration } \\
(\mathbf{p p m})\end{array}$} & MetOH extr. & EtOH extr. & EtOAc Phase & $\begin{array}{c}\text { Hexan } \\
\text { Phase }\end{array}$ \\
\cline { 2 - 5 } & 102.28 & 112.25 & 88.42 & 96.75 \\
10 & 68.69 & 68.27 & 90.92 & 98.94 \\
50 & 92.78 & 78.58 & 33.50 & 111.20 \\
10 & 55.81 & 54.25 & 17.28 & 30.21 \\
250 & 16.69 & 16.73 & 16.65 & 16.35 \\
500 & 15.72 & 16.05 & 16.86 & 16.69 \\
\hline
\end{tabular}

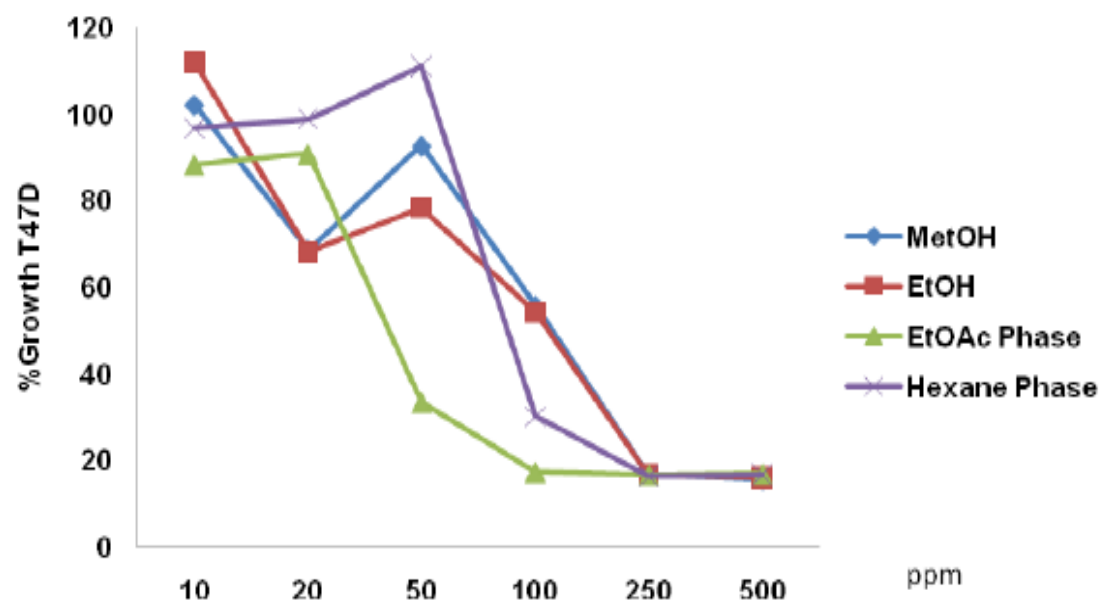

Figure 4. Effect of TFG on growth of T47D cells. The results were plotted as percent of T47D growth (relative cell growth (\%)) versus concentration part permillion (ppm)

Table IV. Percentage growth of Trigonella foenum graecum on PC3 cells $(n=3)$

\begin{tabular}{cccc}
\hline \multirow{2}{*}{$\begin{array}{c}\text { Concentration } \\
(\mathbf{p p m})\end{array}$} & EtOH extr. & MetOH extr. & EtOAc Phase \\
\cline { 2 - 4 } & 93.44 & 87.79 & 75.39 \\
10 & 93.93 & 80.20 & 70.65 \\
20 & 61.66 & 89.15 & 59.65 \\
50 & 57.41 & 59.04 & 58.02 \\
10 & 16.15 & 14.60 & 20.48 \\
250 & 16.27 & 14.52 & 15.05 \\
500 & & & \\
\hline
\end{tabular}




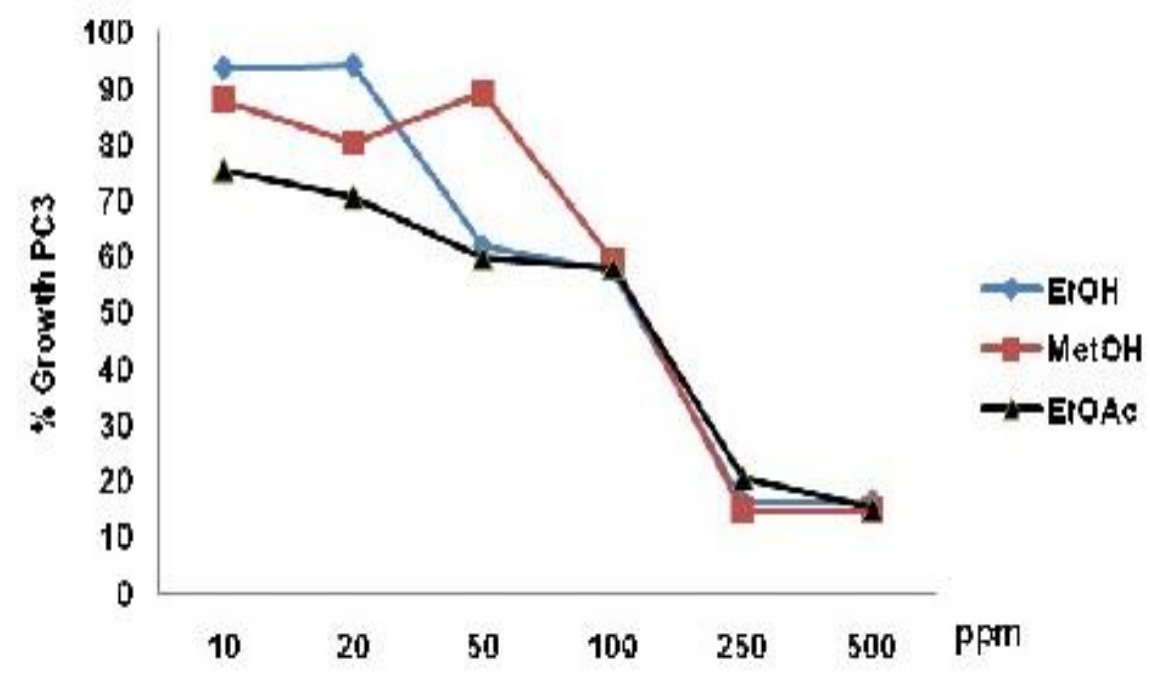

Figure 5. Effect of TFG on growth of PC3 cells. The results were plotted as percent of PC3 growth (relative cell growth (\%)) versus concentration part permillion (ppm)

Table V. IC50 value from some extracts and phases of TFG on PC3, SKOV3, MCF7 and T47D cell-lines. Each data was obtained from six variation concentration with $n=3$

\begin{tabular}{cccc}
\hline No. & Cell-line & Samples of TFG & IC50(ppm) \\
\hline I. & & EtOH Extract & 101.52 \\
2. & PC-3 & MetOH Extract & 99.05 \\
3. & & EtOAc Phase & 66.24 \\
\hline 4. & & EtOH Extract & 230.92 \\
5. & SKOV3 & MetOH Extract & 116.48 \\
6. & & EtOAc Phase & 208.74 \\
\hline 7. & & MetOH Extract & 186.09 \\
8. & & EtOH Extract & 241.24 \\
9. & EtOAc Phase & 41.81 \\
I0 & MCF7 & Hexane Phase & 102.11 \\
II. & BuOH Phase & 136.25 \\
I2. & & Water Phase & 1569.26 \\
\hline I3. & & MetOH Extract & 140.31 \\
I4. & & EtOH Extract & 128.37 \\
I5. & & EtOAc Phase & 58.63 \\
16. & T47D & Hexane Phase & 206.60 \\
\hline
\end{tabular}

Recent studies suggest that TFG and its active compounds may possess anticarcinogenic potential. Raju et al. (2004) showed that diosgenin, a steroid saponin from TFG can inhibit azoxymethane-induced aberrant crypt foci formation in F344 rats and induces apoptosis in HT-29 human colon cancer cells. Also refer from Agustini et al. (2007) that showed that TFG have estrogenic effect on ovariectomized and immature rats. Some phytoestrogens are believed to have selective estrogen receptor modulator (SERM) activity with no action in the uterus but beneficial effects in the hypothalamus/pituitary unit and in the bone and are presently the focus of clinical interest (Wuttke et al., 2003). So it is an interesting phenomena to investigate and screen TFG potency on some cancer cell line, especially cell line with estrogen receptor positive.

Cell lines used in this assay are PC3, SKOV3, MCF7 and T47D which are having hormonal receptor positive. MCF7 and T47D are cell lines from human breast cancer that have estrogen receptor positive. SKOV3 is human ovarian cancer cell lines which is also having estrogen receptor positive. PC3 is human prostate cancer cell-lines with androgen hormone receptor positive. Their activity on cell-lines presented by 
IC50 value, which is means the effective dose/concentration to inhibit $50 \%$ of cell growth.

On PC3 cells, ethyl acetate phase of TFG could inhibit growth of cell more effective (IC50 = $66.24 \mathrm{ppm})$ comparing with methanolic and ethanolic extract. Prostate cancer is a form of cancer that develops in the prostate, a gland in the male reproductive system. Most prostate cancer are slow growing, however, there are cases of aggressive prostate cancers.

On breast cancer cell-line, MCF7 and T47D, also the most effective phase/extract is ethyl acetate phase of TFG with IC50 41.81ppm (on MCF7) and IC50 58.63 ppm (on T47D). Breast cancer (malignant breast neoplasm) is cancer originating from breast tissue, most commonly from the inner lining of milk ducts or the lobules that supply the ducts with milk. Cancer originating from ducts is known as ductal carcinomas those originating from lobules are known as lobular carcinomas. Nowadays, breast cancer treatment, especially with estrogen receptor positive, commonly use tamoxifen, one of SERM group. But the risk of taking this medicine in long time is also high. Many research were done to search another substance in this group, especially from phytoestrogen, which is have estrogenic effect, but effective to treat breast cancer with estrogen receptor positive. Interestingly, Asian women who consume a soy-rich diet (the most famous phytoestrogen) have about a 6-fold lower risk of developing breast cancer than their Western counterparts (Key et al., 1990), and populationbased studies have suggested that consumption of a phytoestrogen-rich diet is protective against prostate and bowel cancer, as well as cardiovascular disease. Hence, it is possible that these phytoestrogens function as chemopreventive agents.

On ovarian cells, methanolic extract of TFG more active than ethanolic extract and its ethylacetate phase. Ovarian cancer is the cancer that forms in tissues of the ovary (one of a pair female reproductive glands in which the ova, or egg, are formed). Most ovarian cancers are either ovarian epithelial carcinomas (cancer that begins in the cells on the surface of the ovary) or malignant germ cell tumors (cancer that begins in egg cells).

Predicted substances of TFG that have estrogenic effect are some sapogenin steroids, such as diosgenin, tigogenin and gitogenin. These substances could bind with estrogen receptor in the cells and compete the inner body estrogen to induce the proliferation.SERM works by blocks estrogen action in breast cell, but can activate estrogen's action in other normal cells, such as bone, liver and uterine cells. These data can be used for further investigation to screen the most active substance of TFG, to find new SERM from phytoestrogen.

\section{CONCLUSION}

Results showed that ethyl acetate fraction gives the lowest IC50 than another extracts. IC50 for PC3 is 66.24 ppm, IC50 for MCF7 is 41.81 ppm, IC50 for T47D is $58.63 \mathrm{ppm}$. These datas can be used for further research to isolate the active compound from TFG.

\section{REFERENCES}

Agustini, K., Sumali W., and Dadang, K., 2005, Pengaruh Pemberian Biji Klabet (Trigonella foenum-graecum L.) terhadap Kadar Hormon Estradiol dan FSH Plasma Tikus Putih Betina Galur Wistar yang Diovariektomi, Prosiding Seminar Nasional Penggalian Potensi Sembilan Tanaman Obat Unggulan Indonesia, Purwokerto.

Agustini, K., Sumali, W. and Dadang, K., 2007, Estrogenic Effect of Fenugreek (Trigonella foenum-graecum L.) on White Female Rats. Conference Proceedings "Women's Health and Traditional Medicine", International Medicine and Medicinal Plants, Surabaya.

Agustini, K., Sumali, W. and Dadang, K., 2005, Efek Estrogenik Biji Klabet (Trigonella foenum graecum L.) Terhadap Perkembangan Uterus Tikus Putih Betina, Jurnal Bahan Alam Indonesia, 4(2).

Annida, B. and Stanley, M.P.P., 2004, Supplementation of fenugreek leaves lower lipid profile in streptozotocininduced diabetic rats, J. Med. Food., 7(2), I53-156

Anonim, 2007, WHO Monograph on Selected Medicinal Plants Volume 3, Otawa, 338-348

Anonim, 1979, Materia Medika Indonesia. Jilid III, Departemen Kesehatan RI, Jakarta: xviii + 196p.

Badziad, A., 2003, Endokrinologi Ginekologi, Media Aesculapius, Fakultas Kedokteran Universitas Indonesia, Jakarta: xxiv + I67p

Bhat, K.P.L, Lantvit, D., Christov, K., Mehta, R.G., Moon, R.C., and Pezzuto, J.M., 200I, Estrogenic and Antiestrogenic Properties of Resveratrolin Mammary Tumor Models, Cancer Research, 6 I , 7456-7463 
Dewick, P.M., 1997, Medicinal Natural Products: A Biosynthetic Approach, John Wiley \& Sons, New York: $x+466 p$.

Evans, C.W., 2002, Pharmacognosy, I5th edition. W.B. Saunders, London: $x i+$ $585 p$.

Ibieta, P., 2005, Interaction of Phytoestrogens with Rat Uterine Estrogen Receptor, Human Sex Hormone-Binding Globulin and Human Breast Adenocarcinoma Cells (MCF-7), PhD Dissertation, Institute for Pharmacy and Molecular Biotechnology. University of Heidelberg.

Key, T.J., Chen, J., Wang, D.Y., Pike, M.C., and Boreham, J., 1990, Sex hormones in women in rural China and in Britain. Br. J. Cancer, 62, 63I-636.

Ma'at, S., 2003, Tanaman Obat untuk Pengobatan Kanker, Jurnal bahan alam Indonesia, 2(4), I46-I 50.

Oh, M., Choi, Y.H., Choi, S.H., Chung, H., Kim, K., Kim, S.I., Kim, D.K., and Kim, N.D., 1999, Antiproliferating effects ginsenoside Rh2 on MCF-7 human breast cancer cells, Intl. Journal of Oncology, I4(5), 869-875.

Raju, Jayadev, Patlolla J.M.R., Swamy, M.V., and Rao, C.V., 2004, Diosgenin, a steroid saponin of Trigonella foenum-graecum (fenugreek), inhibits azoxymethaneinduced aberrant crypt foci formation in F344 rats and induces apoptosis in HT-29 colon cancer cells, Cancer

\section{[iscc. $I I] \mid C l C$}

Epidemiology Biomarkers Prevention, 13(8), 1392 -8.

Rosenbaum, S. M. and Osborne, M. P., 2000, Breast cancer chemoprevention, Am. J. Surg., I80, 249-25I.

Saputra, K., Maat, S., and Soedoko, R., 2000, Terapi Biologi untuk Kanker, Airlangga University Press, Surabaya.

Scheuer, P.J., 1987, Bioorganic Marine Chemistry, Volume I, Spinger-Verlag, Berlin, Heidelberg.

Wiseman, H., 2000, Dietary Phytoestrogens, Oestrogens and Tamoxifens: Mechanisms of Action in Modulation of Breast Cancer Risk and Prevention of Heart Disease. In: Wiseman, Helen, Biomolecular Free Radical Toxicity: Causes and Prevention. John Wiley \& Sons Ltd, Chichester: viii + 246 p.

Wuttke, D.S., Oda, H., Hubertus, J., Volker, C., Barbara, S., Becker, T., and Wuttke, W., 2003, Evidence for selective estrogen receptor modulator activity in a black cohosh (Cimifuga racemosa) extract: comparison with estradiol-17 $\beta$, European Journal of Endocrinology, I49, $35 \mathrm{I}-362$. 